\title{
A Standing International Criminal Court: Step By Step Towards the Enforcement of International Justice
}

\section{Iris Almeida}

\begin{abstract}
The institutional arrangements for the promotion of peace, truth, justice, reparation and reconciliation of countries that are rebuilding democratic institutions following long years of war and conflict, are complex and should necessarily be varied. This article will focus on one salutary global development, namely the adoption of the Rome Statute for the establishment of an International Criminal Court. The author argues that it is essential that states display courage, tenacity and strong political will in actively pursuing the path of international justice and realizing the project of making the court a reality. The article highlights the contribution that civil society organizations including non-governmental Organizations, women's rights groups, academics, journalists, church groups and legal experts can play in educating their fellow citizens and in encouraging states to ratify the Rome Statute. This article approaches the International Criminal Court from three vantage points: First, the opening up of international law to a diversity of actors in the field of human rights; second, the universality of human rights and third, the emerging alliance between some States and civil society actors in ending the cycle of impunity.
\end{abstract}

Iris Almeida is the Director of Programmes of the International Centre for Human Rights and Democratic Development, a Canadian organization with an international mandate. It works with people and governments in Canada and abroad to promote human rights and democratic development through dialogue, advocacy, capacity building, and public education.

\section{Résumé}

Les dispositions institutionnelles pour la promotion de la paix, de la vérité, de la justice, de la reconstruction et de la réconciliation de pays qui cherchent à reconstituer leurs institutions démocratiques après de longues années deguerre et deconflit, sont complexes et ne peuvent qu'être fluctuantes. Le présent article concentre son attention sur un élément salutaire du développement global, nommément l'adoption des Statuts de Rome pour la miseen place d'une Cour Criminelle Internationale. L'auteur présente une argumentation selon laquelle il estcrucial que les états fassent preuve de courage, de ténacité, et d'une ferme volonté politique dans la poursuite active du projet d'une Cour Internationale de Justice, et vers la réalisation effective de ce projet. L'article met en relief le rôle que les organisations issues de la sociétécivile, notamment les organismes nongouvernementaux, les groupes de défense des droits des femmes, les universitaires, les journalistes, les communauté religieuses, lesjuristes, peuvent jouer dans l'éducation de leurs concitoyens et dans la promotion d'une ratification par les états des Statuts de Rome. L'article décrit les trois principaux atouts d'une Cour Criminelle Internationale. D'abord, l'ouverture des lois internationales à une diversité d'acteurs dans le champ des droits humains; ensuite, l'universalisation des droits humains, et finalement l'émergence $d$ 'une alliance entre certains états et certains acteurs issus de la société civile dans l'interruption du cycle de l'impunité.

\author{
Introduction
}

\begin{abstract}
War breeds atrocities. From the earliest conflicts of recorded history to the global struggles of modern times, inhumanities, lust and pillage have been the inevitable by-products of man's resort to force and arms. Unfortunately, such despicable acts have a dangerous tendency to call forth primitive impulses of vengeance and retaliation among victimized peoples. The satisfaction of such impulses in turn breeds resentment and fresh tension. Thus does the spiral of cruelty and hatred grow. If we are ever to develop an orderly international community based upon a recognition of human dignity, it is of the utmost importance that the necessary punishment of those guilty of atrocities be as free as possible from the ugly stigma of revenge and vindictiveness. Justice must be tempered by compassion rather than vengeance. We must insist that the highest standards of justice be applied. Justice Murphy, J., dissenting opinion. Trial of General Yamashita, 327 U.S. 1 (1946) 29.
\end{abstract}

The Twentieth Century is the bloodiest period in the history of humankind. Armed conflicts have killed and maimed millions of people in this century. The United Nations and international relations were dominated by super power rivalry and the defence of their respective hegemonic interests. These blocks and alliances were built strictly within the realm of States and did not include civil society representatives. The perpetrators of heinous crimes were often sheltered from prosecution as long as offending regime remained in power. While the rule of law was flouted and the independence of judiciary was seriously compromised, the international community remained silent.

Today, while international conflicts have ebbed, intrastate conflicts are on the rise. ${ }^{1}$ Not only do these wars and

Refuge, Vol. 18, No. 4 (November 1999) 
conflicts continue to result in massive destruction of property but what is most despicable is that the overwhelming majority of the casualties suffered are civilians caught in the crossfire of the warring factions or used as "human shields." These civilians are not accidental casualties, but the primary targets of attacks; the "laws of war" are violated not by accident but by design and too often as a matter of policy. While the weapons deployed in present day conflicts are primarily conventional armaments, the consequences of the war machine are manifest through indiscriminate killings, torture, rape and maiming of innocent civilians. During World WarII, the percentage of civilian casualties was $5 \%$ and has increased to $80 \%$ in the 1990 s. $^{2}$

The near instantaneous global media coverage highlights in graphic detail stunning images to a world audience, the human cost of some of these conflicts. It brings home the risks and the challenges accompanying the choices of interventions employed by UN member States. Experience has shown that the strategies adopted by the international community in response to such crises and the resources committed to deal with them post facto are too little and too late to be effective. ${ }^{3}$

However, the previous acquiescence of States to massive violations of human rights is slowlybreaking down in many parts of the world. The awareness of the public that the culture of impunity ${ }^{4}$ stifles transitions to democracy is growing. In the face of the egregious atrocities committed in former Yugoslavia and Rwanda, international public opinion, in part, exerted pressure on the United Nations Security Council to act. The sympathy expressed by the public for the victims of "ethnic cleansing" and "genocide", their outrage at the actions of the violators of human rights and the mobilisation of public pressure on governments played a part in the decisions of the United Nations Security Council in setting up the International Criminal Tribunals for the case of Yugoslavia ${ }^{5}$ and $R$ wanda ${ }^{6}$. Despite their numerous constraints, these tribunals through their arduous work have put the spot- light on serious violations of human rights and have increased international awareness on the problem of impunity.

If the enforcement of international justice is to be effective and sustainable, we would need to adequately address three interconnected issues: 1 ) the right of the victims and the rest of society to know the facts; 2) the right to a fair, independent and impartial prosecution; and 3) the right of the victims to reparation for the crimes committed. The search for truth, through the investigation and dissemination of facts, and redress to victims through compensation, reparation, rehabilitation and eventually reconciliation are often subject to the vagaries of "realpolitik". An increasing number of civil society organisations hold the view that the prosecution of alleged criminals responsible for heinous crimes is only one part of an effective plan of action to combat impunity. Michael Reisman so eloquently said:

Courts are indispensable institutions in many domestic criminal and civil systems, and any polity, no matter how structured, must install arrangements, or varying degrees of institutionalisation, to apply the law to concrete cases. But lest we fall victim to a judicial romanticism in which we imagine that merely by creating entities we call " courts " we have solved or prevented major problems, we should review the fundamental goals that institutions designed to protect our public order seek to fulfil. ${ }^{7}$

A question often raised is whether prosecutions, by encouraging vengefulness and inviting a backlash from threatened combatants, can have the effect of unravelling the fragile peace typical of countries emerging from long and bloody civil strife. ${ }^{8}$ Many human rights defenders and a growing number of States, in our view, now believe that peace is not inimical to justice. They are the two sides of the same coin. In this line of reasoning it is better for retribution to be meted out by a court with due process, rather than an indiscriminate continuation of violence and impunity. Plato notes that trials can act as a catharsis for previous wrongs and have the value of deterrence. ${ }^{9}$ Prosecutions also signal the end of past atrocities and enhance the faith of citizens in human rights. As Richard Goldstone, the former Prosecutor of the ICTY and ICTR, said, "I have absolutely no doubt that if there was proper enforcement of humanitarian law, the level of atrocities committed in war would substantially decrease." 10

Currently, efforts in the internationalization of the struggle for human rights are spearheaded by the concerted work of civil society organizations including women's rights activists, academics, national and international non-governmental organizations the world over. These organizations, nationally and internationally, are devising innovative strategies for cooperation and partnership with those States interested in and committed to enforcing international norms and standards, building democratic institutions, fostering democratic participation and accountability. They have grown in strength and numbers since the Vienna World Conference on $\mathrm{Hu}$ man Rights in 1993,11 the Fourth Conference on Women in Beijing in $1995^{12}$ and the United Nations Diplomatic Conference of Plenipotentiaries for the Establishment of the International Criminal Court in $1998 .{ }^{13}$ 
The situation in many countries is a glaring reminder that States have failed to match their rhetoric with action to promote human rights. The challenge is to putinto place effective accountability measures in order to translate the myriad of international covenants, declarations, treaties, resolutions and court decisions into effective rights at the national level, for citizens, victims and the whole of society. Effective action against impunity must start at the national level. However, where the national accountability mechanisms are too weak or compromised to provide justice to the victims, the international community has a responsibility to step in. A growing number of individuals, non-governmental organizations and States have begun to recognize that the principles of sovereignty and non-interference in the internal affairs of a state should not excuse massive and systematic violations of human rights. In fact theState's duty to protect human rights extends not only to its own citizens, but also to the international community as a whole. ${ }^{14}$

This article will focus on one salutary development, the adoption of the Rome Statute for the establishment of the InternationalCriminal Court [hereinafter the Court]. Part I will examine the efforts to set up a Standing International Criminal Court. We will put forward the mosaic of views and actors that formed the canvas of the negotiations in Rome. Part II will appraise key issues addressed in the Rome Statute, drawing, where appropriate, from past jurisprudence. It will focus, in particular, on complementarity with domestic jurisdictions and the innovative treatment of genderrelated crimes. Lastly, Part III will consider the next steps towards the establishment of the Court: the work of the Preparatory Commission, the financing of the Court and, most importantly, the ratification of the Rome Statute.

This article will approach the Court from three vantage points. First, the opening up of international law to a diversity of actors in the field of human rights, second, the universality of human rights and third, the emerging alli- ance between some States and civil society actors in ending the cycle of impunity.

Traditional international law purported only to govern relations between nation-states. It regarded individuals and non-state groups as objects rather than subjects of international law. ${ }^{15}$ International law, because of its primitive nature did not have specialized organs tocreate or to apply norms. ${ }^{16}$ This decentralized mechanism allowed human rights instruments to be dealt with in cosy fora where States criticized each other and where the Cold War geo-strategic interests put aside the criticisms of civil society organizations. The analysis of positivists fails to appreciate the reality of those who suffer the scourge of human rights violations. Kelsen notes "it does not matter if law (domestic or international) is applied or not. Violated or not, the law is the law."17 In the 1990 's, however, non-state actors, from the North and South, have had better access to the UN system. This allows human rights defenders to operate on a diverse range of terrains, from the local to the global system. ${ }^{18}$

These efforts have been challenged by some recalcitrant States who refuse to acknowledge the universal nature of human rights and argue that it is a product of Western culture. However as Preis notes, this cultural relativist position is premised on an outdated concept of culture as integrated, holistic and static, rather than on the understanding developed within anthropology that culture is fragmentary, contested and shifting. ${ }^{19}$ No society is based on such submission to the authorities so as to accept that innocent civilians can be slaughtered at the whim of the leadership. The struggle against impunity for serious violations of human rights clearly draws upon universal principles of human rights and human dignity.

The third issue is the developing alliance of the human rights movement and some States in breaking the cycle of impunity. This movement is imposing on States in a non-voluntarist manner the importance of according the highest value to jus cogens crimes. Thesecrimes refer not only to conventional written international law, ${ }^{20}$ but also to customs and general principles of unwritten international law. ${ }^{21}$ The legal basis of jus cogens crimes consists of international pronouncements, or what can be called international opiniojuris, reflecting the recognition that these crimes are deemed part of generäl customary law. ${ }^{22}$

\section{Part I - Tenacious Efiorts to Create an International Criminal Court}

Cynicshave for many years labelled the Court a pipedream. They have cited the difficulty of apprehending violators of human rights and the concerns expressed by some States on safeguarding national sovereignty and defending their national security interests. While some of these concerns may be legitimate, they need to be balanced with a universal system of enforcing international justice. Moreover, the idea and the efforts to establish an International Tribunal are not new. The Convention on the Prevention and Punishment of the Crime of Genocide ${ }^{23}$ adopted on December $9^{\text {th }} 1948$ envisioned the creation of an international criminal court. The International Law Commission (ILC) prepared a draft treaty but this effort was put on hold once the Cold War set in.

The road to Rome was a long one. The United Nations General Assembly, in 1989, requested the ILC to address the question of establishing an international criminal court and in December 1996, established a Preparatory Committee that prepared a draft text for a Court. The Diplomatic Conference of Plenipotentiaries was organized in Rome from June $15^{\text {th }}$ to July $17^{\text {th }} 1998$ with the objective of negotiating a Statute to establish an International Criminal Court. Interestingly, drug trafficking, the initial impetus for the Court, was left off the agenda in favour of more serious and pressing issues such as genocide, crimes against humanity and war crimes.

Delegations representing 160 countries, 14 United Nations agencies, 17 inter-governmental organizations and 124 non-governmental organizations 
(NGOs) took part in the Diplomatic Conference. Over 700 otherNGOscoordinated their advocacy efforts under the umbrella of the Coalition for an International Criminal Court (CICC) and lobbied States from their respective capitals for several months prior to and during the Conference. The 'consolidated' draft Statute contained 1300 bracketed texts with several options to choosefrom, reflecting the divergence of views on some crucial aspects of the Court. ${ }^{24}$ The non-governmental organizations (NGOs) present did not sit on the sidelines. They enjoyed full access to the Committee of the Whole and the Working Groups and carried out intensive lobbying and advocacy efforts. Many States included NGOs as advisers or members on their official delegations and some government delegations took the initiative to meet with NGOs in order to set out and justify their government's stand on key issues. Civil society advocates participated in the six Preparatory Committees between 1996 and $1998^{25}$ and due to their concerted action were extremely effective during the Rome Conference. The commitment, synergy, effective use of electronic communications, and the flexible strategy to encourage and pressure States at different moments during the Rome Conference produced positive results.

The French were insistent on the need for tempering the role of the Prosecutor and to maintain a high threshold on war crimes. The United States delegation, facing intensive opposition to the Court from the Senate Foreign Relations Committee, was concerned that its peace-keepers would be subjected to politically motivated prosecutions from a potentialbad faith or overzealous prosecutor. The US delegation wanted to ensure that the Court would be under the control of the Security Council, a position shared by the other permanent members of the Security Council.

In Rome, a group of "like-minded" States such as Canada, Australia, Argentina, Chile, Denmark, Sweden, Senegal, South Africa, Singapore and South Korea, joined by approximately fifty others, played a constructive role in the negotiations towards a final RomeStat- ute. This group included many enthusiastic Sub-Saharan African States who made a valuable contribution in ensuring that the Rome Statute reflected not just a court for the poorer underdeveloped countries but also one for the world. NGOs met with the like-minded and exerted pressure on them to demonstrate leadership and to use their strength of numbers in the negotiation of fundamental issues on the agenda.

Agreeing on a Statute that would ensure a strong, independent, effective and permanent Court was an extraordinary challenge. However, the momentum generated by the Preparatory Committee, able leadership by the Chairpersons, the precedents of the Nuremberg, Tokyo, the Hague and Arusha Tribunals and the focus provided by the five weeks of intense political and legal efforts in Rome by the NGOs and the like-minded States helped bring this difficult process to fruition. Of the 148 States present and voting, 120 States voted in favour of establishing the Court, 7 States voted against and 21 States abstained.

The adoption of this Treaty marks a historical moment and is one more step in the international community efforts to end impunity for egregious crimes. Unlike the International Court of Justice, ${ }^{26}$ whose jurisdiction is restricted to States, the Court will have jurisdiction over 'natural persons' irrespective of whether they are political leaders, ordinary citizens or members of the armed forces. ${ }^{27}$ Unlike the Tribunals for the former Yugoslavia and Rwanda, whose jurisdictions are chronologically or geographically limited, the Court will be permanent and, subject to extensive ratification, has the potential for global reach.

\section{Part II - An Appraisal of the Fundamental Challenges Addressed}

In order to gain universal acceptance, the Court will focus on crimes of the "most serious concern to the international community as a whole ${ }^{28}$ : Genocide, crimes against humanity, war crimes and, when a definition has been agreed upon, aggression. Furthermore, some treaty crimes found their way into the Rome Statute, albeit in a modified form, such as Crime of A partheid under Crimes against Humanity.

The Rome Statute does not permit any reservations. ${ }^{29}$ The Lawyers Committee for Human Rights, Amnesty International, The International Centre for Human Rights and Democratic Development, Human Rights Watch and numerous national and international NGOs advocated against reservations. Human Rights Watch stressed that "permitting reservations would undermine the force and moral authority behind a Treaty and weaken the nature of the obligations embodied in it. ${ }^{30}$

We will discuss four fundamental issues addressed at the Conference: the definition of crimes, the jurisdiction of the Court, its complementarity with national courts and the inclusion of gender sensitive provisions in the Rome Statute.

\section{Defining the Crimes Covered- 1.1 Crime of Genocide: "The Crime of all Crimes."}

In article 6 of the RomeStatute, the Crime of Genocide is defined in a manner identical to article II of the Convention on the Prevention and Punishment of the Crime of Genocide. ${ }^{31}$ The Crime of Genocide is defined as:

Any of the following acts committed with intent to destroy, in whole or in part, a national, ethnical, racial or religious group, as such;

(a) Killing members of the group;

(b) Causing serious bodily or mental harm to members of the group;

(c) Deliberately inflicting on the group conditions of life calculated to bring about its physical destruction in whole and in part;

(d) Imposing measures intended to prevent births within the group;

(e) Forcibly transferring children of the group to another group.

The judgement by the Tribunal for Rwanda in Prosecutor v. Akayesu, ${ }^{32}$ and a few judgements by national courts as in A.G. Israel v. Eichmann, ${ }^{33}$ and Minister of Citizen- 
ship and Immigration (Canada) v. Mugesera ${ }^{34}$ provide judicial interpretation. First, "killing members of a group" does not refer to involuntary homicideor unpremeditated killing. An offender must intend to destroy in whole or in part, a protected group. Second, the Rwanda Tribunal noted that the harm need not be permanent and irremediable and included rape and other forms of sexual violence in this provision. Third, "inflicting conditions of life" may include acts relating to "subjecting a group of people to a subsistence diet, systematic expulsion from their homes and the reduction of essential medical services below the minimum requirement." 35

Fourthly, "imposing measures to prevent births" is clarified in the Genocide Convention, and by the A.G Israel vEichmannjudgement, ${ }^{36}$ as such measures that could include sterilization, compulsory abortion, segregation of the sexes and obstacles to marriage ${ }^{37}$ In the Akayesu case, the Tribunal for Rwanda went further, stating: "In patriarchal societies, where membership of a group is determined by the identity of the father, an example of a measure intended to prevent births within a group is the case where during rape, a woman of the said group is deliberately impregnated by a man of another group, with the intent to have her give birth to a child who will consequently notbelong to its mother's group." ${ }^{38}$ The five acts enumerated aboveencompass forms of physical and biological genocide but not cultural genocide, intentionally omitted by the drafters of the Genocide Convention in $1948 .{ }^{39}$ Efforts to enlarge the definition of the crime of Genocide to extend to linguistic groups and to political, economic and social groups in the Rome Statute did not meet with success.

\subsection{Crimes Against Humanity - in International and Non- International Conflicts}

In Article 7 of the Rome Statute, crimes against humanity include acts such as murder, enslavement, forcible transfer of population, imprisonment in violation of fundamental rules of interna- tional law, torture, persecution against any identifiable group on political, racial, cultural and other grounds, the crime of Apartheid, and other inhumane acts of a similar character, where they are knowingly committed as part of a systematic or widespread attack against a civilian population. These crimes have been elaborated by several treaties and tribunals. These include the Hague $^{40}$ and Geneva Conventions on humanitarian law in time of war. ${ }^{41}$ Since the Second World War, there has been a consistency in the definition of Crimes against Humanity in international treaties such as the 1968 Convention on the Non-Applicability of Statutory Limitations for War Crimes and Crimes against Humanity, ${ }^{42}$ and in the statutes of international tribunals such as the Statute of the International Military Tribunal at Nuremberg, ${ }^{43}$ the International Military Tribunal for the Far East, ${ }^{44}$ the Tribunal for the Former Yugoslavia ${ }^{45}$ and the Tribunal for Rwanda. ${ }^{46}$

The RomeStatute states the criteria of "widespread or systematic" as a key requirement for attacks directed against any civilian population to be considered a crime against humanity. "Widespread" is a term that refers to "the number of victims". ${ }^{47}$ It refers to actions carried out collectively and on a large scale. The term "systematic" excludes random acts of violence." ${ }^{48}$ The "civilian" population includes all persons who have not taken any active part in hostilities, or are no longer doing so. ${ }^{49}$ Of particular significance is the inclusion of gender-related crimes that are defined under 1 (g) as "rape, sexual slavery, enforced prostitution, forced pregnancy, enforced sterilization or any other form of sexual violence of comparablegravity". For the first time an international treaty recognizes the crime of persecution against any identifiable group or collectivity on grounds of gender. ${ }^{50}$ Lastly, a critical affirmation is that crimes against humanity could occur both in times of peace and in situations of armed conflict.

\subsection{War Crimes - Raising the Threshold}

Article 8 of the Rome Statute provides an exhaustive list of war crimes provisions. Many States including the United States and France expressed concerns with these provisions and advocated high thresholds. War Crimes are punishable as individual acts, do not require any special intent element and do not normally need to be widespread or systematic. However, the RomeStatute in Article 8 (1) expressly states that the Court shall have jurisdiction in respect to war crimes, in particular, when committed as part of a plan or policy, or as part of a large-scale commission of such crimes.

War Crimes include thirty-four crimes relating to international conflicts and, sixteen crimes relating to noninternational conflicts. The Rome Statute essentially codifies the Hague Conventions and the 'gravebreaches' of the four Geneva Conventions as well as its Additional Protocols. The RomeStatute codifies a list of gender related crimes similar to those listed as crimes against humanity.

Another subject of contention relates to the issue of child soldiers. Globally it is estimated that there are over 300,000 child soldiers. ${ }^{51}$ At the insistence of the US delegation, the compromise language adopted is not recruitment but "conscripting or enlisting children under the age of fifteen years into the national armed forces or using them to participate actively in hostilities." 52 The most difficult provision to resolve related to the prohibition of nuclear weapons and landmines. There was strong opposition from the major military powers and the largest exporters of such weapons; namely China, Russia and, in particular, the United States. The Rome Statute prohibits the use of asphyxiating, poisonous or other gases, and all analogous liquids, materials or devices $^{53}$ and bullets that expand or flatten easily in the human body. ${ }^{54}$ Reference to landmines, chemical and nuclear weapons are absent from the RomeStatute. 


\subsection{The Crime of Aggression: Ambiguity, Disagreement and Postponement}

This crime will only come under the jurisdiction of the Court once state parties amend the RomeStatute so as to provide for a definition of this currently ambiguous crime. The negotiators could not reach agreement over this issue, primarily due to the insistence of the permanent members of the Security Council that the Council play a significant role in ascertaining when aggression has occurred.

\section{Engendering the Rome Statute \\ - Inclusion of Gender Concerns}

Gender-based violence has traditionally not been addressed in international humanitarian law. Rape was first mentioned as a Crime against Humanity in Control Council Law No 10, produced by the Allied powers occupying Germany. ${ }^{55}$ There were no prosecutions of rape in trials conducted on the basis of this instrument for a long time. The International Military Tribunal for the Far East found that approximately 20,000 cases of rape occurred with the city of Nanking during the first month of occupation. Sadly, there were no prosecutions. Despite the rhetoric of States on their commitment to ensure the full enjoyment by women of all human rights, violations of the human rights of women have traditionally been neglected. These violations are ignored and often times dismissed as a "natural consequence" of war.

This attitude has begun to change with work of the Tribunals for the former Yugoslavia and Rwanda. Article 5 para. (g) of the Statute of the ICTY and article 3 para. $(\mathrm{g})$ of the Statute of the ICTR expressly include rape as a crime againsthumanity. At the Rome Conference, a concerted advocacy campaign was spearheaded by the Women's Caucus on Gender Justice to include specific provisions on gender specific crimes. It met with wide support from most nongovernmental organizations and some States. Gender related crimes apply to international and non-international conflicts and are explicitly listed in both
Crimes against Humanity and War Crimes. ${ }^{56}$ The Rome Statute is the first international treaty recognizing the crime of forced pregnancy. Under Crimes against Humanity it includes the crime of persecution against any identifiable group or collectivity on grounds of gender. ${ }^{57}$ In addition to the crimes of enforced prostitution and enslavement, the crime of sexual slavery is codified, thus recognizing that the coerced nature of sexual services goes well beyond the crime of slavery. Finally, Article 21 (3) states that "the application and interpretation of law must be... without any adverse distinction founded on grounds such as gender, age, race, colour, language, religion or belief, political or other opinion, national, ethnic or social origin, wealth, birth or other status".

The Holy Sea and Ireland, backed by some African and Latin American States and a significant number of States in the Arab League, 58 mounted a concerted attack on the inclusion of "forced pregnancy" and the term "gender". They were joined by pro-life activists, mainly from North America, who mounted an aggressive campaign. Their efforts partially failed as these terms were retained. However in an effort to deal with the controversy, the Rome Statute contains a provision which reads "the term 'gender' refers to both sexes, male and female, within the context of society".59

On an institutional level, the Rome Statute provides for criteria in the selection of judges taking into accounta " fair representation of female and male judges." ${ }^{100}$ It also stipulates the need to include judges ${ }^{61}$ and advisers appointed by the Prosecutor who havelegal expertise on specific issues such as violence against women and children. ${ }^{62}$ The Registrar is to set up a Victim and Witness Unit to provide, in consultation with the Office of the Prosecutor, protective measures and counselling services. The Unit is to include staff with expertise in trauma, including trauma related to crimes of sexual violence. ${ }^{63}$

\section{Jurisdiction of the Court}

The Rome Statute establishes that the jurisdiction of the Court applies to any natural person ${ }^{64}$ over 18 years of age ${ }^{65}$ who commits a crime within the jurisdiction of the Court, irrespective of official capacity. ${ }^{66}$ The jurisdiction of the Court is non -retroactive ${ }^{67}$ and applies only to crimes committed once the Rome Statute comes into force and the Court is established. Among the international community, calls have been made to hold criminally responsible the authors of crimes committed in Cambodia, Burundi, Congo (Zaire), and Algeria. These will require ad hoc international criminal tribunals to be established. Further, the Rome Statute sets important preconditions to the exercise of jurisdiction by the Court. The State on the territory of which the conduct in question occurred (territorial state) or the State of which the person accused of the crime is a national (state of nationality of the accused) should be party to the RomeStatute. ${ }^{68}$ A state not party to the Treaty may choose to file an ad-hoc declaration consenting to the Court's jurisdiction over a specific crime in question. ${ }^{69}$ The criteria for determining jurisdiction does not take into account the identity of the state that has custody of the accused or the state of the victim.

Further still, taking into consideration the concern of France, an important exception is made to the jurisdiction of the Court, which, in the view of many, is contrary to international law and practice. A transitional provision in Article 124 allows a State Party to opt out of the jurisdiction of the Court over War Crimes committed on its territory or by its nationals for a period of seven years after the entry into force of the Rome Statute.

This state consent regime is viewed by many international law experts and human rights defenders as both limiting and cumbersome. On the issue of the selection process of cases, the International NGOCoalition in Romejoined by many like-minded States advocated strongly that if the decision to trigger the Court was left to States Parties and the Security Council, it would compromise 
the Court's impartiality and integrity. First, the perception of undue political influence in the initiation of the proceedings may arise. Second, the experience of other international treaties that envisage a state complaint procedure has so far proved that these mechanisms are not effective as diplomatic concerns and economic interests most often take precedence. ${ }^{70}$ Third, Security Council actions are hampered by the 'veto' power of the permanentmembers of the Security Council. In addition, its mandate under Chapter VII of the UNCharter ${ }^{71}$ - to maintain and restore international peace and security would create a risk that the Court would prosecute for politically expedient reasons. It was recognized, however, that referral of a case by the Security Council has the singular characteristic that it is binding on all UN member States, whether or not the States are parties to the Rome Statute. In spite of a contentious debate on the role and powers of the Security Council, which risked jeopardizing the consensus arrived at on other points during the Rome Conference, the negotiators managed to ensure co-operation and avoid subordination of the Court to the Security Council. The resulting compromise is that in order to suspend or delay an investigation or prosecution, the Security Council must adopt a resolution to that effect. The resolution operates a one-year suspension, but can be renewed by a new resolution. ${ }^{72}$ However, as a positive vote is required, eight members of the Security Council have to vote in favour of such a resolution and none of the Permanent members must vote against. Action by the Courtcan be triggered in one of three ways: as a referral by a State party, as a referral by the Security Council acting under Chapter VII powers of the United Nations Charter and by the Prosecutor propio motu.

Article 15 of the Rome Statute represents a positive step in the struggle for international justice. It provides the Prosecutor the power to determine whether the case justifies an investigation, based on information from any reliable source. This provides an opportunity for individuals, victims and friends of the Court including NGOs, to bring violations to the attention of the Court. The Prosecutor is required toconsult the State before taking "non-compulsory measures" such as interviewing voluntary witnesses. Before launching an investigation, the Prosecutor must request authorization to investigate from the Pre-Trial Chamber, a judicial body of the Court. The mechanism set up thus allows States to participate in investigations but precludes them from hindering the judicial process.

\section{Complementarity: Working in Concert with National Courts and States Parties}

The Rome Statute seeks to balance the concerns of States who believe that national courts have primary criminal law jurisdiction and the need for justice where domestic courts are unwilling or unable to proceed. Interestingly, in order to determine a state's unwillingness in a specific case, the Court will assess whether the actions of the state demonstrate an attempt to shield a person from criminal responsibility, whether there has been any delay in the national proceedings inconsistent with an intent to bring the alleged criminal to justice, and whether the proceedings are being conducted independently or impartially. ${ }^{73}$ To determine a state's inability, the Court will consider, having regard to the principles of due process recognized by international law, whether the state is unable to take the accused into custody, to gather the necessary evidence and testimony and to carry out the proceedings. ${ }^{74}$ These decisions may be subject to a review on appeal. At the present time, judicial systems in many countries are discredited for their lack of autonomy from the Executive branch of government or a lack of separation of powers from other branches of government. This is compounded in many developing countries by procedural and structural deficiencies such as scarce resources, excessively formal procedures, heavy caseload and inability of a majority of citizens to access the courts.

The principle of complementarity, supported by all States at the Confer- ence, insures that the Court will respect the state's sovereign right to investigate or prosecute a case over which it has jurisdiction. Article 17 envisages that a case could be challenged not only where the State itself is investigating or prosecuting or has prosecuted but also where a state has decided not to proceed with a prosecution, unless the decision was due to the inability or unwillingness of the State.

Upon ratification, the Treaty becomes part of the national law of the State that ratifies it. The Court is to become an extension of national jurisdiction, relying upon the cooperation of States parties to carry out its functions and to enforce its order. To mention some examples, this cooperation may include, among other matters, the arrest and surrender of a person, collection of evidence, protection of victims and witnesses and seizure of the proceeds of crimes. The Court may also make requests for cooperation from non-state parties. The Court does not itself have the power to order state compliance. In situations where a state party refuses to cooperate, the Court could make a finding to that effect, and refer the matter to the Assembly of States parties or, in some cases, to the Security Council. The Assembly of States parties provides the management oversight ${ }^{75}$ to the Court and nominates itsjudges, ensuring that each has a role in the operation of the Court.

The Rome Statute is a product of many a compromise. The adoption of the Rome Statute and the breadth of support reflected in the results of the vote demonstrates that there is, in the international community today, a growing consensus in favour of an institutional instrument for human rights.

\section{Part III - The Next Steps - Towards the Enforcement of International Human Rights}

Neither the NGOs nor individualStates claim to be fully satisfied with the end product - the Rome Statute. Yet with some distance and closer review and reflection many agree that on balance it is a good statute, the best we could possibly get at this time. The Rome Statute 
marks a step forward for the civil society's goals without precluding further campaigns. As an indication, the most significant deficiency - the limitations on the jurisdiction of the Court - can be progressively overcome by efforts to universally ratify the Rome Statute.

Three primary challenges remain to be addressed. Firstly, the work of the Preparatory Commission, ${ }^{76}$ particularly relating to rules of procedure and evidence and the elements of crime. Secondly, the financing of the Court. Lastly, the urgent need for ratification of the Rome Statute by at least 60 States.

\section{Work of the Preparatory Commission}

From the start of the proceedings, there was general agreement that the subject matter of deliberations and proposals should not deviate from the Rome Statute. Elements of Crime refer to the elements of acts that must be proven by the Prosecutor in order to establish culpability for a crime. One of the major issues included the level of intent for culpability. The US proposed raising the level of intent to commit genocide to require awareness of a wider policy of genocide and action in furtherance of this wider policy. ${ }^{77}$ A compromise was reached in informal discussion raising the intent requirement to include the extra - and easier to prove - objective element that "the accused knew or should have known".

With regard to rules of Procedure and Evidence, some of the contentious issues had do to with the French proposals to set elaborate rules that seem to infringe on the independence of the Prosecutor. However, they are gearing up to makea very valuable contribution in highlighting the role of victims. The work of the Commission, to be completed by June 2000 , will assist tremendously the process of ratification by States of the Rome Statute by reducing the level of uncertainty about the operation of the Court. However, it highlights the need for vigilance on the part of States and civil society toprevent the development of rules that undermine the progress achieved in Rome.

\section{Financing}

The financing of the Court is a crucial question which relates to the potential effectiveness, independence and influence of the Court. A lack of funds for the establishment and operations of the Court could lead to politically biased or expedient choices and a reduction in the quality of its operations. States were split between two choices for financing the Court: funding by States Parties to the Treaty and funding out of the United Nations general budget. Some States argued that the regularbudget of the UN is a more reliable source of funding, would add to the universal character of the Court and encourage poorer States, otherwise shy of the costs of the Court, to support its creation.

The United States argued that the Court would be aheavy drain on the UN budget and that the Court would have to compete for resources among the myriad of UN priorities. The RomeStatute stipulates that the expenses of the Court and the Assembly of State Parties shall be provided both by contributions made by state parties and funds provided by the United Nations, the latter, in particular, for expenses incurred by Security Council referrals". ${ }^{8}$ In addition, the Court will accept voluntary contributions.

Learning from the experience of the Tribunals for the former Yugoslavia and Rwanda is crucial. Creative ways will have to be found to avoid unjustified delays and to ensure efficiency and transparency in the management of personnel and procurement. The amount of political, and thereby financial, support will depend in near term on the number of States Parties to the Court and the quality of its judgements once it begins operations.

\section{Ratification of the Rome Statute}

Presently, 82States have become signatories to the Rome Statute. Senegal became the first state to ratify the Rome Statute, followed by Trinidad and Tobago and San Marino. ${ }^{79}$ Belgium, Luxembourg, Italy and France have commenced the ratification process.
The record of ratification for many of the treaties that relate to the subject matter of the Court is positive. The International Covenant on Civil and Political Rights $^{80}$ took ten years to come into force and has 140 ratifications. Its Optional Protocol (which includes international oversight mechanisms) ${ }^{81}$ also took ten years and has 93 ratifications. The GenocideConvention $^{82}$ took three years and has 124 ratifications.

The early ratification by States of this treaty is crucial so as to maximize on the momentum generated in Rome and the recent decision on the Pinochet case by the Law Lords in Great Britain. ${ }^{83}$ An effective strategy for civil society to encourage ratification should focus on: first, ensuring progress in the work of the Preparatory Commission so as to encourage States to design enabling legislation domestically; second, promoting public awareness on the Rome Statute. Third, encouraging key supporter States to lead the way in ratification. Fourth, States, international agencies and NGOs should continue concerted efforts to provide technical and legal assistance to States to change domestic legislation to comply the Rome Statute. Fifth, using available up-coming international events and forums, such as the Summit of the Americas, to keep the issue of ratification on the agenda, formally and informally.

In States with amnesty laws in place, as is the case in the Americas, it is important to emphasize the Court's complementarity with national courts and the non-retroactivity of its jurisdiction. There is a need to appreciate the concerns of States who voted against the Statute and every effort should be made to continue the dialogue with them. However, any attempt to reopen the Rome Statute and dilute its contents or attempts to exploit loopholes so as to undermine the Court should be vigorously opposed and publicly exposed. It has been alleged that the United States is making such an attemptby approaching States supportive of the Court, such as South Africa and Poland, and signing agreements whereby these States promisenot to give up any UScitizens to the Court. ${ }^{84}$ This is consistent with Ar- 
ticle 98 of the Rome Statute, which precludes the Court from making a request for surrender or assistance that would require a state to act inconsisten $\mathrm{t} 1 \mathrm{y}$ with its obligations under international law to a third party, unless the consent of the third party is given.

\section{Conclusion}

The adoption of the Rome Statute on July $17^{\text {th }} 1998$ marks a watershed in the struggle to end the impunity enjoyed by perpetrators of egregious crimes. There were seven major welcome outcomes of the Rome Conference which had been advocated by civil society organizations, namely: 1) the provision for an Independent Prosecutor; 2) the inclusion of crimes committed during noninternational armed conflict; 3) the recognition of gender related crimes, such as forced pregnancy and sexual slavery; 4) the creation of a Victim and Witness Protection Unit; 5) the exclusion of the death penalty; 6) the refusal to permit reservations to the Rome Statute; and 7) the diversity of funding sources for the Court.

Many compromises were made in Rome in order to get a large number of States to support the adoption of the Treaty. Foremost on the list are: 1) the limitation on the Court's jurisdiction where investigation is not triggered by the Security Council; 2) the non- inclusion of nuclear weapons and landmines in the list of prohibitive weapons; and 3) the inclusion of the seven year opt-out provision on war crimes.

As Cherif Bassiouni said, "The ICC will not be a panacea for all the ills of humankind. But it can help avoid some conflicts, prevent some victimization and bring tojustice some of the perpetrators of these crimes. In so doing, the ICC will strengthen world order and contribute to world peace and security."8s To secure an effective Court, it is essential that States display courage, tenacity and strong political will and proceed with ratification of the Rome Statute. Civil society organizations including nongovernmental organizations, women's rights groups, academics, journalists, church groups and legal experts have a major role to play in edu-

Refuge, Vol.I8,No.4 (November1999) cating fellow citizens and encouraging States to ratify the Rome Statute. Making the International Criminal Court a reality, a universal instrument for retributive and restorative justice in a fractured world, will be a modest, yet worthwhile step forward for the whole of humankind. II

Notes

1. SIPRI 1997: Armament, Disarmament and International Security (Oxford, Oxford University Press, 1998)

2.0.Ramsbotham\&T. Woodhouse,Humanitarian Intervention in Contemporary Conflict:

A Reconceptualisation (Cambridge: Cambridge University Press, 1996).

3. Joint Evaluation of Emergency Assistance to Rwanda, The International Response to Conflict and genocide: Lessons from the Rwanda Experience, (Synthesis Report) (Denmark: Steering Committee of the Joint Evaluation of Emergency Assistance to Rwanda, March 1996), at 11

4. E/CN.4/Sub.2/1993/6. Impunity is defined as the impossibility, de jure or de facto, of bringing criminal proceedings against the perpetrators of human rights violations, as well as civil, administrative or disciplinary proceedings, since they are not subject to any inquiry that might lead to their being accused, arrested, tried and if found guilty, accused, arrested, tried and if found guilty,
convicted and given appropriate convicted and given appropriate
punishment, including reparation for the punishment, including reparation for the harm suffered to their victing. De facto impunity occurs w acts in question are in practice from the normal operation of the legal system. De jure impunity occurs when the legislature provided exemption of legal responsibility for acts committed in a particular context. This impunity includes clemency measures, prescription, and allowing mitigating circumstances during the trial stage.

5. Statute of the International Criminal Tribunal for the Former Yugoslavia, S.c. Res 827, Annex [hereinafter Tribunalfor Yugoslavia].

6. Statute of the International Criminal Tribunal for Rwanda,S.C. Res. 955, Annex [hereinafter Tribunal for Rwanda].

7. W. M. Reisman, "Legal Responses to Genocide and Other Massive Violations ofHuman Rights" (1996) 59 Law and Contemporary Problems 69 at 69 .

8 .. S. Huntington, "The Third Wave: Democ ratization in the Late Twentieth Century" in N.J. Kritz (ed.) Transnational Justice, Vol.
I, (Washington: United States Institute of Peace, 1995) 69 at 81

9. Plato, Protagoras (New York: Macmillan, 1956).

10.R. Goldstone, "Assessing the "IN or $k$ of the United Nations War Crimes Tribunals" (1997) Stanford Journal of International Law 1 at 4 .

11. Vienna Declaration and Programme of Action, U.N.Doc.A/CONF/157173 (12 July 1993).

12. Beijing Declaration and Programme of Action, U.N. Doc. A/CONF /177 120 (15 September 1995).

13. Rome Statute of the International Criminal Court, UN Doc. A/CONF.183/9 [hereinafter Rome Statute].

14. See M. Robinson, Human Rights at the Dawn of the 21st Century, concluding remarks of the General Rapporteur, Interregional meeting organized by the Council of Europe, Palais de l'Europe, Strasbourg, 2830 January 1993.

15. 1. Cotler, "Human Rights as the Modern Tool of Revolution" in K. Maho ey \& P. Mahoney, eds., Human Rights in the TwentyFirst Century: A Global Challenge (Dordrecht : Martinus NijhoffPublishers, 1993) 7 at 11.

16. H. Kelsen, Theorie pure du droit, $2 \mathrm{~d}$ ed., trans. C. Eisenmann (Paris: Dalloz, 1962) at 425.

17. Ibid

18. S.E. Merry, "Global Human Rights and Local Social Movements in a Legally Plural World" (1997) $12: 2$ Canadian Journal of Law and Society 244, at 250.

19. A-B. S. Preis, "Human rights as Cultural Practice: An Anthropological Critique" (1996) 18 Hum. Rts. Q. 286 at 298.

20. Statute of the International Court of Justice, 26 June 1945, 59 stat. lOSS, T.s. No 993 [hereinafter ICJ Statute] Article 38 par. 1 lit.a.

21. ICJ Statute, 38 par. 1 lit. b, c.

22. M. Ackerhurst, "Custom as Source of International Law" 1974 British Yearbook of International Law 1.

23. 9 December 1948, 78 U.N.T.s. 277.

24. Report of the Preparatory Committee on the Establishment of an International Criminal Court, UN Doc. (A/CONF.1831 Add.2 1998).

25. Report of the Preparatory Committee on the Establishment of an International Criminal Court, Volume 1 UN Doc. AI 51/22,1996 and Report of the Preparatory Committee on the Establishment of An International Criminal Court, UNDoc. AI CONF.1831 Add.2, 1998 
26. ICJ, Art 34 (1) Only States may be parties to cases before the Court.

27. Explicitly set out in Rome Statute of the International Criminal Court, art. 27, UN Doc. A/CONF.183/9 [hereinafter Rome Statute].

28. Ibid. Preamble, paragraph 4.

29. BGBi. Nr. 4031980; international source: 8 I.L.M. 679. (Under article 2 par. 1 (d) of the Vienna Convention on the Law of Treaties, a reservation means "a unilateral statement, however phrased or named made by a State, when signing, ratifying, accepting, approving or acceding to a treaty, where it purports to exclude or modify the legal effect of certain provisions of the treaty in their application to that State.")

30. Human Rights Watch, Commentary for the March-April 1998 Preparatory Committee Meeting on the establishment of an International Criminal Court, 9. Also see Lawyers Committee for Human Rights, International Criminal Court Briefing Series, Vol. I, Number 7 (1998); Amnesty International, The International Criminal Court, Making the Rights Choices - Part IV. Establishing and Financing the Court and Final Clauses (March 1998) 23.; \& International Centre for Human Rights and Democratic Development, Brief on the International Criminal Court, 2 May 1998.

31. Convention on the Prevention and Punishment of the Crime of Genocide, 9 December 1948, 78 U.N.T.S. 277 [hereinafter Genocide Convention].

32. Prosecutor v. Akayesu, 1CTR -96-4-T (on appeal).

33. A.G. Israel v. Eichmann, (1968) 36 I.L.R. 18 (D.C.), para. 19

34. Minister of Citizenship and Immigration $v$. Mugesera , File No. QML-95-00171, July 11, 1996. (Immigration and Refugee Board Adjudication Division), reported (in French) in (1996) 7 Rev. Univ. Droit de l'Homme 190.

35. Prosecutor v. Akayesu. ICTR -96-4-T (on appeal).

36. A.G. Israel v. Eichmann, (1968) 36 I.L.R. 18 (D.C.), para. 224

37. UN Doc. E/623/Add.2;UN Doc. E/447, p 26 ; UN Doc. A/C.6/SR.82.

38. Prosecutor v. Akayesu, 1CTR -96-4-T (on appeal).

39. UN Doc. A/c.6/SR.83.

40. Convention with Respect to the Laws and Customs of Waron Land, The Hague, (Hague Convention II) 29 June 1899.

41. 1907 Hague Convention (IV) Convention Respecting the Laws and Customs of War on Land, Preamble, par. 8; Convention for the Amelioration of the Condition of the Wounded and Sick in Armed Forces in the Field (First Geneva Convention), Aug. 12 1949, 6 UST 3114,75UNTS31, article 63; Convention for the Amelioration of the Condition of the Wounded, Sick and Shipwrecked Members of Armed Forces at Sea (Second Geneva Convention), Aug. 12 1949, 6 UST 3217, 75 UNTS 85, article 62; Convention Relative to the Protection of Prisoners of War (Third Geneva Convention), Aug. 12, 1949, 6 UST 3316, 75 UNTS 135, article 142; Convention Relative to the Protection of Civilian Persons in Time of War (Fourth Geneva Convention), 6 UST 3516, 75 UNTS 287, article 158; Protocol Additional to the Geneva Conventions of Aug 12,1949 , and relating to the Protection of Victims of International Armed Conflicts (First Add. Prot,), article 1 para2; Protocol Additional to the Geneva Conventions of Aug 12,1949 , and relating to the Protection of Victims of Non-International Armed Conflicts (Second Add. Prot.), Preamble.

42. GA Res. 2391 (XXIII) of Nov. 26, 1968, art. 1. Para. b.

43. Charter of the International Military Tribunal for Nuremberg, Article6(c).G.A.Res.95(I), 1 U.N. GAOR, U.N. Doc A/64/Add. 1, 188 (1946).

44. Charter of the International Military Tribunal for the Far East, Article 5 (c). Jan. 19, 1946, T.I.A.S. No. 1589

45. Statute of the International Criminal Tribunal for Yugoslavia, S.C. Res. 827, Article 5.

46. Statute of the International Criminal Tribunal for Rwanda, S.C. Res. 955, Article 3.

47. Prosecutor v. Tadic (Case. No. IT-94-1AR72), Judgement of the Appeals Chamber, para 648, October 2, 1995.

48. Prosecutor v. Akayesu, Judgement, Case No. ICTR-96-4-T, ("Akayesu Judgement"), Sept. 2, 1998, para 579.

49. M. Boot, R. Dixon \& C K. Hall Crimes Against Humanity p. 47. (Both the Tadic Judgement and the Akayesu Judgements adopted this definition).

50. Rome Statute, art. 7(1) (h)

51. Coalition to Stop the Use of Child Soldiers (1999) online: Coalition to Stop the Use of Child Soldiers <http://www.childsoldiers.org/>(date accessed: 27 May 1998).

52. Rome Statute, art. 8 (2) (b) (xxvi).

53. Ibid. Art. 8 (2) (b) (xxviii)

54. Ibid. Art 8 (2) (b) (xix)

55. Control Council Law No.10. Punishment of Persons Guilty of War Crimes, Crimes Against Peace and Crimes Against Humanity, 20 Dec. 1945, Official Gazette of the Control Council for Germany, No.3.
56. Rome Statute, art. 8 (2)(b) (xxii) for international armed conflict and 8 (2) (c) (vi) for non-international armed conflict.

57. Ibid. Art. 7 (1) (h).

58. States that made statements opposing the inclusion of the term gender are: Bahrain Brunei, Egypt, Guatemala Kuwait, Saudi Arabia, Syria, Qatar, Turkey, United Arab Emirates, Oman, Venezuela and Yemen. The Syrian and Qatar delegates took the lead on these negotiations

59. Rome Statute, art. 7 (3).

60. Ibid. Art 36 (8) (a) (iii).

61. Ibid. Art. $36(8)$ (b)

62. Ibid. Art. 42 (9).

63. Ibid. Art. 43 (6)

64. Ibid. Art. 25 (1)

65. Ibid. Art. 26

66. Ibid. Art. 27 (1) \& (2).

67. Ibid. Art. 24 (1)

68. Ibid. Art 12 (2) (a) \& (b).

69. Ibid. Art 12 (3).

70. Article 41 of the International Covenanton Civil and Political Rights; Article 21 of the Convention against Torture; $45 \& 61$ of the American Convention on Human Rights and Article 47 of the African Charter on Human and Peoples Rights have state complaint mechanisms that have not yet been put to use.

71. Charter of the United Nations, 26 June 1945, Can. T.S. 1945, and no.7. Chapter VII Article 39 notes "the Security Council shall determine the existence of any threat to the peace, breach of the peace, or act of aggression and shall make recommendations, or decide what measures shall be taken."

72. Rome Statute. Article 16.

73. Rome Statute art. 17 (2) (a)(b)(c).

74. Ibid. art. 17 (3).

75. Ibid. art 112 (2) (a).

76. Ibid. Final Act, Resolution F.

77. UN Doc. PCN/ICC/1999/DP.9.

78. Rome Statute art. 115 part 12.

79. Senegal ratified the Statute on 2 February 1999, Trinidad and Tobago on 6 April 1999 and San Marino on 13 May 1999.

80. U.N.T.S., vol. 99, p 171.

81. Ibid. Vol. 99 , p.171

82. Ibid., vol. 78, p. 277

83. Regina $v$. Bartle and the Commissioner of Police and others Ex-Parte Pinochet. 1999. A.C. (H.L.)

84. International Centre for Human Rights and Democratic Development, ICC Bulletin \#2, May 181999.

85. C. Bassiouni, "Preface" in O. Triffterer (ed.), Commentaryon the Rome Statute of the International Criminal Court (Baden-Baden: Nomos Verlagsgesellshaft, 1999) 13 at 15. 


\section{REPORTS}

\section{- Somali Refugees in Toronto:} A Profile

By Edward Opoku-Dapaah, 1995 ISBN 1-55014-278-x, 130 pp., \$12.95.

This is the first comprehensive study of Somali refugees in Toronto. It examines the social, residential, and linguistic characteristic of Somalis, their participation in the local economy, and the activity of Somali community organizations. The report also contains valuable suggestions and recommendations concerning suitable and more efficient service delivery to this community.

\section{- Cambodian Refugees in Ontario:} An Evaluation of Resettlement and Adaptation

By Janet McLellan, 1995

ISBN 1-55014-267-4, 142 pp., \$12.95.

This major study of Cambodian refugees in Ontario examines the effects of various forms of sponsorship on Cambodian resettlement. It also focuses on the linguistic, economic, educational, training and social dimensions of the whole process of adaptation. The delivery of services by governmental and NGO agencies as well as the effects of the past traumatic experiences of genocide and mass starvation on Cambodian refugees are fully discussed.

- Refugee Families and Children: A Directory for Service Providers in Metro Toronto

Compiled by

John Morris and Lydia Sawicki, 1995

ISBN 1-55014-285-2, 39 pp., \$6.95.

This directory is designed for service providers who work with refugee families and children in Metro Toronto. Its aim is to improve service provision through networking and the sharing of training opportunities.

\section{Available from:}

Centre for Refugee Studies

\section{Back Issues of Refuge, Canada's periodical on refugees}

1. Environmentel Refugees, Vol 12, No. 1, June 1992

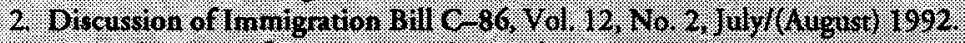

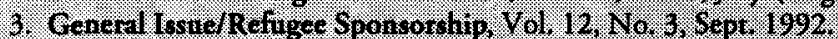

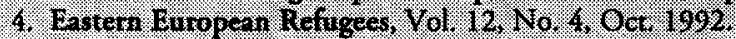

5. The Tragedy of Somall, Yol, 12, No. 5, Novernberd Deceniber 1992 .

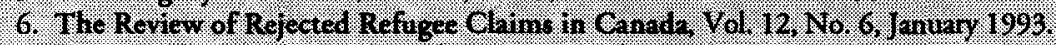

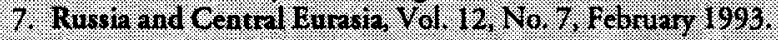

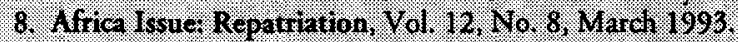

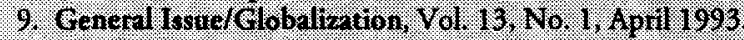

10. Russia and Centril Eurasia. Yol. 13. No. 2. May 1993.

11. Special Is ue on Sri Iarila. Vol. 13. No. 3, I Une 1993.

12. Cender Issules and Refigee Law, Vol. 13 , No. 4. I Uly A Aigust 1993.

13. Soudheast Asian Refugees, Vol. 13. No. 5, Sept. 1996.

14. Nozambican Refugees, Vol. 13 . No. 6, October 1993.

15. Rusbia and Central Eurasia, Yol, 13, No. 7, Novernbet/ December 1993.

16. General Issuel Sudan, Vol. 13. No. 8 . January 1994.

17. Integration of Refigecs. The Canadiun Eqperience, Vol. 13. No. 9, Eebruaty 1994

18. Refugees and Peace in Gentral America, Vol. 13, No. 10, March 1994.

19. Hors of Arice. Yol. I4. No. 1. April 1994.

20. The Russinn Federtion, Vol. 14. No. 2, May 1996.

21. The Former Yrgoslana, Vol. 14, No. 3. Junelluly 1994.

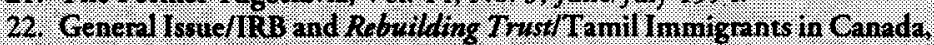

Vol. 14, No. 4, Augustrsepreniber 1994.

23. Rwandan Crisis, Vol. 14, No. 5, October 1994

24. Refuger Reserdement in lerad, Vol. 14, No. 6, Novernber 1994.

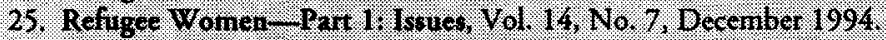

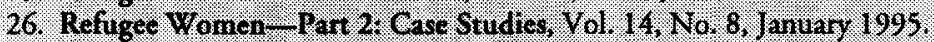

27. The Safe Third Countey Concept. Vol. 14, No. 9. February 1995.

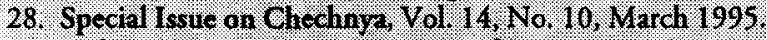

29. Reformulation of Interational Refugec Law. Vol. 15. No. $1,1996$.

30. Enviromment, Developmeat and Refugees, Vol. 15.1 1o. 2, 1996.

31. International Intervention in Refugeo Grises, Yol, 15, No. 3.1996.

32. Early Warning on Mimanitatian Ctises, Vol. I5, No. 4, 1996.

33. Child Refugees, Vol. 15, No. 5, 1996.

34. Global Sentement Services. Vol. 15, No. 6, 1997 .

35. Early Warning and Early Response, Vol, 16, No. 1, May 1997.

36. Uprooting and Consequences, Vol. 16. No. 2, June 1997.

37. Developmentinduced Displacement, Vol, 16, No. 3, Alggust 1997.

38. Refugee and Immigrant Womer. An International Perspective, Vol. 16, No. 4 , October 1997.

39. Working with Refugees and Intemally Displaced Persons, Vol. 16, No. 5, Nov. 1997.

40. Conflict, Population Displacement, and Conflict Resolution, Vol, 16, No. 6, Dee. 1997.

41. Refugee and Immigrant. Women. An International Peropective. Pat. II, Vol. 17 , No. 1 . February 1998 .

42. Human Rights and Refugee Movernents in the Newly lhitependent States of the Former Soviet Union, Vol. 17 , No. 2, April 1998.

43. Current Issues In Refugee and Muman Rights Policy and Researd, Yol. 17, No. 3 . August 1998.

44. Violent Displacernent and Post-Conflict Reconstruction. Afghanistan, Uganda, and Rwanda, Vol. 17, No. 4, October 1998.

45. New Cargo: The Clobal Business of T rafficing in Women. Yol. 17, Na. 5, Nov. 1998.

46. Critical Perspectives on Refisees. Vol, 17, No.6, December 1998.

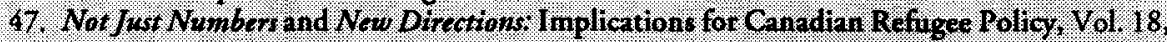
No. 1, February 1999

47. Conflict, Human Rights, and Integration of Refugess, Vol. 18, No. 2, A.pll 1999.

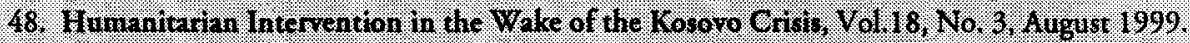

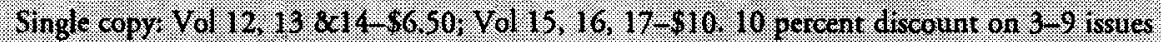

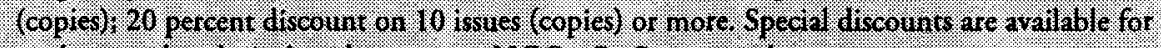

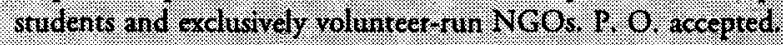

Dlease send your orders ros

Centre for Reftiged Studies. York. University

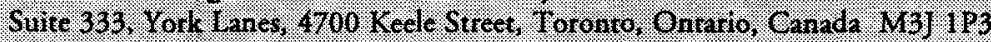

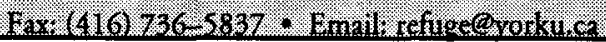


Phone: (416) 736-5663

Fax: (416) 736-5837

Email: refuge@yorku.ca

\section{East Timor:}

\section{Just Another Human Tragedy?}

\section{Guest Editor: Steve Hansch}

The Centre for Refugee Stuties, York University. Toronto, will publish a spectal issue of Refuge, Canada's Periodical on Refugees, on "East Timor - Just Another Fuman Tragedy?".

The issue will address topics such as:

- Historical and regional background.

- The root causes of the conflict.

- The quest for peace and impediments.

- The dilemma of refugees, returnees and internally displaced persons (IDP).

- Protection and assistance of refugees, retumees and IDPs.

- Repatriation and return in conflict.

- Picking up the pieces: reconstructing war-tom East Timor.

- The roles of national and intemational organizations in providing humanitarian assistance, peace-building andreconstruction of East Timor:

- Conflict resolution: Regional and global perspectives.

Contributions with abstracts are invited. They must be received not later than November 22, 1999. Papers should be typed, double-spaced, and referenced in prop peracademic form. They should not exceed 16 pages or about 4000 words. Short papers of about 900 words are also welcome. A short abstract $100-150$ words) must accompany as well as 2 . sentence (institutional) identifcation of the author. AII submission should be word-processed with computerized software and sent on disc or by e-mail attaciment:

Onaccepte aussi des articles en frangais. Lestgle doitconformer auxnormes exígés pour les articles rédigés en anglais.

Deadline:December 15, 1999.

For further details, please contact:

Stere Honsch, Guest Editor: Or

Himanitarian Affairs Director:

Congressional Hunger Center:

Washington, DC, USA

Prof Wichael Lamplitier, Editor

Refuge (Canudas Periodical on Refugees)

Centre forRefugeestudies, York University.

Sutte 322, York Larnes, 4700 K Keele Street

Toronto, Ontario, Canada M3I IP3

Fore $(416) 736-5837$ : Tell. (416) $736-5843$ or $(416) 736-5663$

E-mail shoiritirnet

E-maillanphier Oyorkuca 